\title{
Flotation of zinc and lead oxide minerals from Olkusz region calamine ores
}

\author{
Krystian Cichy ${ }^{1, a}$, Cezary Regula ${ }^{2}$ and Grazyna Pajor ${ }^{2}$ \\ ${ }^{1}$ Institute of Non-Ferrous Metals, ul. Sowinskiego 5, 44-100 Gliwice, Poland \\ ${ }^{2} Z G H$ "Boleslaw" S.A., Poland
}

\begin{abstract}
The paper presents chemical and mineralogical characteristics of calamine ore from the Pomorzany mine. A flowsheet for recovery of sulphide minerals of zinc and lead in the form of the $\mathrm{Zn}-\mathrm{Pb}$ bulk concentrate was presented. In the following part, preparation of the feed for flotation of $\mathrm{Zn}-\mathrm{Pb}$ oxide minerals and optimal conditions for separation from it iron sulphide minerals, represented by marcasite, were determined. In the final section the results of flotation of $\mathrm{Zn}-\mathrm{Pb}$ oxide minerals with anionic collector AM2 belonging to the hydroxyamide group of collectors and a cationic collector in the form of a coconut amine, being a mixture of primary aliphatic amines, were presented. Basing on the obtained results, a technological flowsheet for the recovery of $\mathrm{Zn}-\mathrm{Pb}$ sulphide and oxide minerals from the calamine ore of the Pomorzany mine was presented.
\end{abstract}

\section{Introduction}

Lead and zinc was produced in Poland from calamine ores by using the Waelz process. The extracted ore was subjected to roasting in the presence of coke as a reducing agent. As a result the so-called raw zinc oxide, which was the raw material for production of metallic zinc and lead was achieved. The high costs of the process were the reason for stopping, in the early 90 -ies of the twentieth century, production of lead and zinc from the calamine ore using this method.

The calamine ores are the final results of transformation of sulphide deposits of $\mathrm{Zn}-\mathrm{Pb}$ under the influence of surface water enriched in oxygen. The zinc and lead minerals are usually in the form of carbonate minerals such as smithsonite and monheimite (zinc) and cerussite (lead). Their formation is a result of reaction of acidic sulphate solutions arising from oxidation of metal sulphides contained in the ore with the surrounding carbonate rocks such as calcite and dolomite. As a result formation of secondary carbonate minerals of zinc and lead takes place.

Due to the similarity of surface properties of carbonate minerals of zinc and lead to the surrounding waste rock, which is mostly dolomite, their flotation has not yet been sufficiently resolved. So far, the studies have shown that the only practical flotation method of oxide ore of $\mathrm{Zn}-\mathrm{Pb}$ beneficiation is the so-called Rey method involving sulphidizing the surfaces of minerals by sodium sulphide and their flotation with primary aliphatic amines having the hydrocarbon chain length of $\mathrm{C}_{12}$ $\mathrm{C}_{16} \cdot[1,2]$

${ }^{a}$ Corresponding author: krystianc@imn.gliwice.pl 
Due to the fact that the surface of carbonate minerals has in aqueous medium a negative charge and amine is a cationic collector, it is necessary to separate slimes from the feed prior to flotation because the cationic collector can be adsorbed by the electrostatic forces and it will finally result in transfer the slimes to the froth product.

The necessity of the initial desliming of the feed significantly reduces in practice the range of application of this method due to high losses of metals in the removed slime fraction. Another disadvantage of this method is a good collecting ability of aliphatic amines with respect to the sulphide minerals of iron, which have, as natural sulphides, under these conditions, much better floatability than sulphidized carbonate minerals of $\mathrm{Zn}-\mathrm{Pb}$.

The necessity of the initial desliming of the feed and flotation of iron sulphide minerals considerably reduces the use of this method due to the high losses of metals in the removed products. Its use can be economically justified only in case of enriching the very rich $\mathrm{Zn}-\mathrm{Pb}$ oxide ores.

The aim of this study is to investigate whether flotation recovery of $\mathrm{Zn}-\mathrm{Pb}$ oxide minerals is possible with other than amines collectors, which do not require costly and troublesome sulphidation.

\section{Characteristics of studied ore}

The subject of research was the calamine ore from the Pomorzany mine which is currently the only active mine in Poland that extracts the $\mathrm{Zn}-\mathrm{Pb}$ ore. The chemical analysis of studied ore is shown in Table 1.

Table 1. Chemical analysis of studied calamine ore from the Pomorzany mine.

\begin{tabular}{|c|c|c|c|c|c|c|c|c|c|c|}
\hline \multicolumn{10}{|c|}{ Content, \% } \\
\hline $\mathbf{Z n}$ & $\mathbf{Z n}(\mathbf{O})$ & $\mathbf{Z n}(\mathbf{S})$ & $\mathbf{P b}$ & $\mathbf{P b}(\mathbf{O})$ & $\mathbf{P b}(\mathbf{S})$ & $\mathbf{F e}$ & $\mathbf{F e}(\mathbf{O})$ & $\mathbf{F e}(\mathbf{S})$ & $\mathbf{C a O}$ & $\mathbf{M g O}$ \\
\hline 5.58 & 3.61 & 1.97 & 0.95 & 0.73 & 0.23 & 43.70 & 29.93 & 13.77 & 2.44 & 0.93 \\
\hline
\end{tabular}

The chemical analysis indicates that the tested ore is almost an iron ore with significant additions of zinc and lead, in which there is practically no waste rock. A basic mineralogical composition of the ore is as follows:

$\begin{array}{cc}\text { Mineral } & \text { Distribution, \% } \\ \text { galena } & 0.3 \\ \text { cerussite } & 1.0 \\ \text { sphalerite } & 2.9 \\ \text { marcasite } & 29.6 \\ \text { monheimite } & 13.3 \\ \text { goethite } & 46.8 \\ \text { dolomite } & 6.2 \\ \text { Sum } & 100.0 \%\end{array}$

The main mineral in the studied ore is goethite constituting nearly $47 \%$ of the composition, while the second the most abundant component is marcasite, which is sulphide mineral of iron in the amount of approx. $29.6 \%$. In total iron minerals constitute more than $76 \%$ of the ore. The main zinc minerals are monheimite and sphalerite occurring in amounts of approx. $13.3 \%$ and $2.9 \%$, while lead minerals are cerussite and galena in the amounts of approx. $1.0 \%$ and $0.3 \%$. Such a composition of the ore shows that the basic difficulty in the process of enrichment is the presence of iron oxide minerals represented by goethite forming the smallest particles of slime. 


\section{Determination of the optimal conditions for the recovery of zinc and lead sulphide minerals}

Flotation concentrate containing $\mathrm{Zn}-\mathrm{Pb}$ oxide minerals can be directed for processing by the Waelz process provided that firstly the $\mathrm{Zn}-\mathrm{Pb}$ sulphide minerals are removed, because their presence in the process is undesirable due to the sulphur content. Accordingly, the first step is to determine the optimal conditions for flotation of galena and blende.

Due to a significant amount of goethite, which is a potential source of slime fraction generated in grinding, the ore grinding is limited to the standard particle size $<0.2 \mathrm{~mm}$ carried out in a laboratory rod mill. The analysis of particle size distribution and chemical content of feed for flotation is given in Table 2.

Table 2. Analysis of particle size distribution of feed for flotation.

\begin{tabular}{|c|c|c|c|c|c|c|c|c|}
\hline \multirow{2}{*}{$\begin{array}{c}\text { Grain class } \\
\text { mm }\end{array}$} & \multirow{2}{*}{$\begin{array}{c}\text { Yield } \\
\%\end{array}$} & \multicolumn{7}{|c|}{ Content, \% } \\
\hline & & $\mathbf{Z n}$ & $\operatorname{Zn}(\mathbf{O})$ & $\% \frac{\mathrm{Zn}(\mathrm{O})}{\mathrm{Zn}}$ & $\mathbf{P b}$ & $\mathrm{Pb}(\mathrm{O})$ & $\% \frac{\mathrm{Pb}(\mathrm{O})}{\mathrm{Pb}}$ & $\mathbf{F e}$ \\
\hline$>0.2$ & 4.32 & 5.30 & 3.31 & 62.45 & 0.91 & 0.73 & 80.22 & 43.70 \\
\hline $0.2-0.1$ & 10.28 & 6.80 & 4.03 & 59.26 & 0.76 & 0.62 & 81.60 & 39.40 \\
\hline $0.1-0.071$ & 10.32 & 6.20 & 3.84 & 61.94 & 0.95 & 0.70 & 74.01 & 46.17 \\
\hline $0.071-0.035$ & 14.00 & 5.47 & 3.41 & 62.30 & 1.00 & 0.76 & 76.14 & 43.15 \\
\hline$<0.035$ & 61.08 & 5.34 & 3.62 & 67.79 & 0.96 & 0.69 & 71.70 & 42.25 \\
\hline Sum & 100.00 & 5.60 & 3.64 & 65.09 & 0.94 & 0.70 & 73.77 & 42.55 \\
\hline
\end{tabular}

The presented particle size distribution shows that in the feed for flotation there is a significant amount of ultrafine grains $<0.035 \mathrm{~mm}$ of approx. $60 \%$, which is the result of overgrinding of goethite. A small amount of galena in the studied ore was the reason for separation of the $\mathrm{Zn}-\mathrm{Pb}$ sulphide minerals in the collective enrichment flowsheet. The study of bulk flotation process was conducted in the laboratory pneumatic-mechanical flotation machine of IZ type with a chamber volume of 2.51 . In the first stage, the tests of the bulk flotation of galena and blende were carried out with the feed without desliming, and in the next stage with the deslimed feed. Desliming was performed in a laboratory hydrocyclone $\phi 50 \mathrm{~mm}$ with particle cutsize of approx. $10 \mu \mathrm{m}$. The flotation conditions were as follows: density $400 \mathrm{~g} / \mathrm{l}, \mathrm{CuSO}_{4} 350 \mathrm{~g} / \mathrm{t}, \mathrm{NaX}$ iso-amyl $25 \mathrm{~g} / \mathrm{t}$, Mileflot X-23 $15 \mathrm{~g} / \mathrm{t}, 20 \mathrm{~g} / \mathrm{t}$ and $25 \mathrm{~g} / \mathrm{t}$, Corflot $5 \mathrm{~g} / \mathrm{t}$, flotation time $15 \mathrm{~min}$. Table 3 presents the results of the preformed tests of $\mathrm{Zn}-\mathrm{Pb}$ bulk flotation.

Table 3. Results of bulk flotation of $\mathrm{Zn}-\mathrm{Pb}$ sulphide minerals from the feed not deslimed and after desliming.

\begin{tabular}{|c|c|c|c|c|c|c|c|c|}
\hline \multirow{2}{*}{$\begin{array}{c}\text { Flotation } \\
\text { conditions }\end{array}$} & \multirow{2}{*}{ Product } & \multirow{2}{*}{$\begin{array}{c}\text { Yield } \\
\% \\
\end{array}$} & \multicolumn{3}{|c|}{ Content, $\%$} & \multicolumn{3}{|c|}{ Recovery, \% } \\
\hline & & & $\mathbf{Z n}$ & $\mathbf{P b}$ & $\mathbf{F e}$ & $\mathbf{Z n}$ & $\mathbf{P b}$ & $\mathbf{F e}$ \\
\hline \multirow{3}{*}{$\begin{array}{l}\text { Not deslimed } \\
\text { feed }\end{array}$} & Feed & 100.00 & 5.52 & 0.94 & 43.36 & 100.00 & 100.00 & 100.00 \\
\hline & $\mathrm{C} \mathrm{ZnS}+\mathrm{PbS}$ & 13.26 & 8.42 & 0.90 & 37.40 & 20.23 & 12.70 & 11.44 \\
\hline & $\mathrm{T} \mathrm{ZnS}+\mathrm{PbS}$ & 86.74 & 5.08 & 0.95 & 44.27 & 79.77 & 87.30 & 88.56 \\
\hline \multirow{5}{*}{ Deslimed feed } & Feed & 100.00 & 5.54 & 0.96 & 43.92 & 100.00 & 100.00 & 100.00 \\
\hline & Slime & 15.76 & 5.30 & 1.03 & 42.00 & 15.08 & 16.91 & 15.07 \\
\hline & HC underflow & 84.24 & 5.58 & 0.95 & 44.28 & 84.92 & 83.09 & 84.93 \\
\hline & $\mathrm{C} \mathrm{ZnS}+\mathrm{PbS}$ & 7.52 & 23.37 & 1.62 & 28.95 & 31.73 & 12.69 & 4.96 \\
\hline & $\mathrm{T} \mathrm{ZnS}+\mathrm{PbS}$ & 76.72 & 3.84 & 0.88 & 45.78 & 53.19 & 70.40 & 79.97 \\
\hline
\end{tabular}


The introduction of desliming operation resulted in a significant improvement of the enrichment indices, both in terms of improving concentrate quality and metals recovery.For determination of the final indices of recovery of $\mathrm{Zn}-\mathrm{Pb}$ sulphide minerals corresponding to the industrial conditions, the flotation tests were carried out using the flowsheet with the cleaning flotations to obtain $\mathrm{Zn}-\mathrm{Pb}$ concentrate as in commercial operation. This flowsheet is shown in Fig. 1, while the balance of the enrichment process in Table 4.

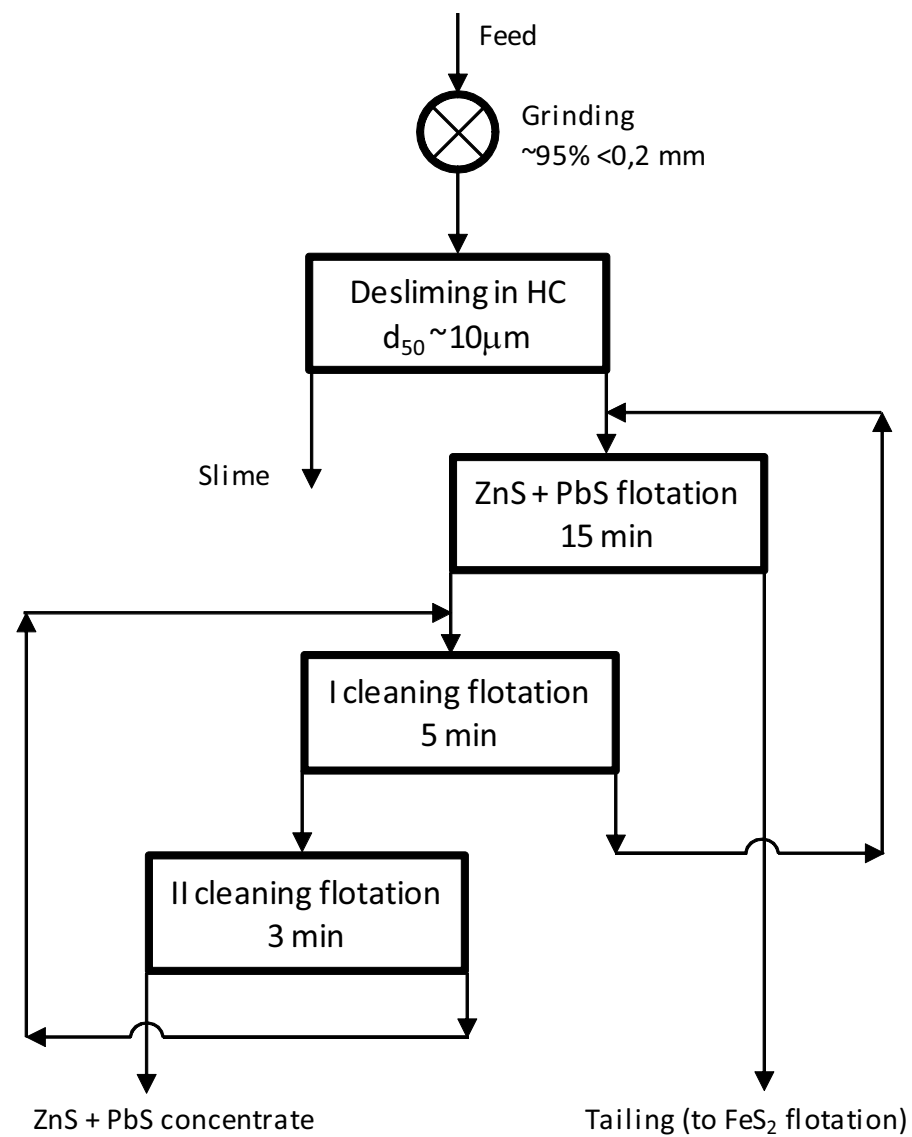

Figure1. Flowsheet for $\mathrm{Zn}-\mathrm{Pb}$ sulphide minerals recovery from calamine ore of the Pomorzany mine.

Table 4. Balance of the recovery process of $\mathrm{Zn}-\mathrm{Pb}$ sulphide minerals from calamine ore of the Pomorzany mine.

\begin{tabular}{|c|c|c|c|c|c|c|c|}
\hline \multirow{2}{*}{ Product } & Yield & \multicolumn{3}{|c|}{ Content, \% } & \multicolumn{3}{|c|}{ Recovery, \% } \\
\cline { 3 - 8 } & $\mathbf{\%}$ & $\mathbf{Z n}$ & $\mathbf{P b}$ & $\mathbf{F e}$ & $\mathbf{Z n}$ & $\mathbf{P b}$ & $\mathbf{F e}$ \\
\hline Feed & 100.00 & 5.61 & 0.97 & 43.51 & 100.00 & 100.00 & 100.00 \\
Slime & 15.53 & 5.27 & 1.06 & 42.38 & 14.59 & 16.97 & 15.13 \\
\hline $\mathrm{HC}$ underflow & 84.47 & 5.67 & 0.95 & 43.72 & 85.41 & 83.03 & 84.87 \\
$\mathrm{C} \mathrm{ZnS}+\mathrm{PbS}$ & 2.59 & 53.24 & 3.54 & 5.32 & 24.62 & 9.47 & 0.32 \\
$\mathrm{~T} \mathrm{ZnS}+\mathrm{PbS}$ & 81.88 & 4.17 & 0.87 & 44.93 & 60.79 & 73.56 & 84.56 \\
\hline $\mathrm{M} 1 \mathrm{ZnS}+\mathrm{PbS}$ & 6.99 & 12.66 & 1.58 & 30.18 & 15.78 & 11.37 & 4.85 \\
$\mathrm{M} 2 \mathrm{ZnS}+\mathrm{PbS}$ & 2.08 & 25.40 & 2.66 & 18.81 & 9.40 & 5.70 & 0.90 \\
\hline
\end{tabular}




\section{Determination of the optimal conditions for flotation of iron sulphide minerals}

The next stage of preparation of ore for flotation of $\mathrm{Zn}-\mathrm{Pb}$ oxide minerals was to determine the conditions of flotation of iron sulphide minerals.

The mineralogical analysis shows that about $30 \%$ of the ore is iron sulphide represented by marcasite. In practice, it is known that almost all of the collecting reagents for flotation of $\mathrm{Zn}-\mathrm{Pb}$ oxide minerals are also good collectors of sulphide minerals including iron minerals. In the case of avoiding flotation of marcasite prior to flotation of oxides, the oxide concentrate would contain significant quantities of marcasite, reducing its quality both in terms of zinc content and increased sulphur content. It is therefore apparent that there is a need for this operation, before flotation of oxides.

The material used in this study was the tailing of bulk flotation of galena and blende. The examined parameters of marcasite flotation was the dose of sodium ethyl xanthate and the addition of sodium sulphide to refresh its surface.

Flotation conditions were as follows: density approx. $350 \mathrm{~g} / \mathrm{l}, \mathrm{NaX}$ ethyl $75 \mathrm{~g} / \mathrm{t}, 100 \mathrm{~g} / \mathrm{t}, 100 \mathrm{~g} / \mathrm{t}+$ $\mathrm{Na}_{2} \mathrm{~S} 500 \mathrm{~g} / \mathrm{t}$, Corflot $5 \mathrm{~g} / \mathrm{t}$, time of flotation $15 \mathrm{~min}$. The results are shown in Table 5.

Table 5. Results of $\mathrm{FeS}_{2}$ flotation from $\mathrm{Zn}-\mathrm{Pb}$ bulk flotation tailings from calamine ore of the Pomorzany mine.

\begin{tabular}{|c|c|c|c|c|c|c|c|c|}
\hline \multirow{2}{*}{ Flotation conditions } & \multirow{2}{*}{ Product } & \multirow{2}{*}{$\begin{array}{c}\text { Yield } \\
\% \\
\end{array}$} & \multicolumn{3}{|c|}{ Content, \% } & \multicolumn{3}{|c|}{ Recovery, \% } \\
\hline & & & Zn & $\mathbf{P b}$ & $\mathbf{F e}$ & $\mathbf{Z n}$ & $\mathbf{P b}$ & $\mathbf{F e}$ \\
\hline \multirow{3}{*}{$\mathrm{NaX}$ ethyl $-75 \mathrm{~g} / \mathrm{t}$} & Feed & 100.00 & 4.14 & 0.87 & 44.91 & 100.00 & 100.00 & 100.00 \\
\hline & $\mathrm{C} \mathrm{FeS}_{2}$ & 19.78 & 0.65 & 0.77 & 41.60 & 3.11 & 17.50 & 18.32 \\
\hline & $\mathrm{T} \mathrm{FeS}_{2}$ & 80.22 & 5.00 & 0.89 & 45.73 & 96.89 & 82.50 & 81.68 \\
\hline \multirow{3}{*}{$\mathrm{NaX}$ ethyl - $100 \mathrm{~g} / \mathrm{t}$} & Feed & 100.00 & 4.16 & 0.83 & 44.72 & 100.00 & 100.00 & 100.00 \\
\hline & $\mathrm{C} \mathrm{FeS}_{2}$ & 23.87 & 0.62 & 0.75 & 40.25 & 3.56 & 21.57 & 21.48 \\
\hline & $\mathrm{T} \mathrm{FeS}_{2}$ & 76.13 & 5.27 & 0.86 & 46.12 & 96.44 & 78.43 & 78.52 \\
\hline \multirow{3}{*}{$\begin{array}{c}\mathrm{Na}_{2} \mathrm{~S}-500 \mathrm{~g} / \mathrm{t} \\
\mathrm{NaX} \text { ethyl }-100 \mathrm{~g} / \mathrm{t}\end{array}$} & Feed & 100.00 & 4.18 & 0.85 & 44.80 & 100.00 & 100.00 & 100.00 \\
\hline & $\mathrm{C} \mathrm{FeS}_{2}$ & 26.44 & 0.71 & 0.80 & 44.28 & 4.49 & 24.88 & 26.13 \\
\hline & $\mathrm{T} \mathrm{FeS}_{2}$ & 73.56 & 5.43 & 0.87 & 44.99 & 95.51 & 75.12 & 73.87 \\
\hline
\end{tabular}

The results indicate that, for the maximum removal of iron sulphide minerals before flotation of oxide minerals of zinc and lead, it is necessary to add to the flotation suspension sodium sulphide in the amount of approx. $500 \mathrm{~g} / \mathrm{t}$. Under these conditions, the maximum degree of marcasite removal with the iron content of the froth product close to the theoretical Fe content of the mineral is noted. Tailing from the flotation of marcasite constituted the feed for the flotation of oxide minerals of zinc and lead.

\section{Study of collecting properties of reagents from the hydroxyamide group and primary aliphatic amines for $\mathrm{Zn}-\mathrm{Pb}$ oxide minerals}

Literature survey shows that for flotation of oxide minerals of zinc and lead, besides the aliphatic primary amines, hydroxyamides may also be used. In terms of chemistry, this reagent is a potassium salt of hydroxyamide, while the physical form is paste which is highly soluble in water. The tested reagent was AM2 hydroxyamide (AXIS HOUSE, Republic of South Africa). According to the manufacturer, this reagent shows favourable results for flotation of oxide minerals of non-ferrous metals, especially copper.

For the purpose of flotation a $2 \%$ aqueous solution was used. First, flotation of oxide minerals of zinc and lead from calamine ore (without sulphide zinc, lead and iron minerals) was carried out without feed sulphidation. The parameter of the flotation process was the dose of this reagent. The 
flotation conditions were as follows: density approx. $300 \mathrm{~g} / \mathrm{l}, \mathrm{AM} 2100 \mathrm{~g} / \mathrm{t}, 150 \mathrm{~g} / \mathrm{t}$ and $200 \mathrm{~g} / \mathrm{t}$, Corflot $5 \mathrm{~g} / \mathrm{t}$, flotation time $12 \mathrm{~min}$. The flotation test results with the addition of this reagent are shown in Table 6.

Table 6. Flotation results of $\mathrm{Zn}-\mathrm{Pb}$ oxide minerals from calamine ore of the Pomorzany mine using AM2 hydroxyamide without sulphidation process.

\begin{tabular}{|c|c|c|c|c|c|c|c|c|}
\hline \multirow{2}{*}{$\begin{array}{l}\text { Flotation } \\
\text { conditions }\end{array}$} & \multirow{2}{*}{ Product } & \multirow{2}{*}{$\begin{array}{c}\text { Yield } \\
\%\end{array}$} & \multicolumn{3}{|c|}{ Content, \% } & \multicolumn{3}{|c|}{ Recovery, \% } \\
\hline & & & Zn & $\mathbf{P b}$ & $\mathbf{F e}$ & Zn & $\mathbf{P b}$ & $\mathrm{Fe}$ \\
\hline \multirow{3}{*}{$\begin{array}{l}\text { AM2 } \\
100 \mathrm{~g} / \mathrm{t}\end{array}$} & $\begin{array}{c}\text { Feed } \\
\left(\mathrm{T} \mathrm{FeS}_{2}\right)\end{array}$ & 100.00 & 5.32 & 0.88 & 44.83 & 100.00 & 100.00 & 100.00 \\
\hline & $\mathrm{C} \mathrm{ZnO}+\mathrm{PbO}$ & 11.26 & 7.32 & 0.93 & 37.62 & 15.49 & 11.90 & 9.45 \\
\hline & $\mathrm{T} \mathrm{ZnO}+\mathrm{PbO}$ & 88.74 & 5.07 & 0.87 & 45.74 & 84.51 & 88.10 & 90.55 \\
\hline \multirow{2}{*}{$\begin{array}{c}\text { AM2 } \\
150 \mathrm{~g} / \mathrm{t}\end{array}$} & $\begin{array}{c}\text { Feed } \\
\left(\mathrm{T} \mathrm{FeS}_{2}\right)\end{array}$ & 100.00 & 5.27 & 0.85 & 44.67 & 100.00 & 100.00 & 100.00 \\
\hline & $\mathrm{C} \mathrm{ZnO}+\mathrm{PbO}$ & $\begin{array}{l}14.32 \\
85.68\end{array}$ & $\begin{array}{l}7.64 \\
4.87\end{array}$ & 0.95 & 38.94 & 20.76 & 16.00 & 12.48 \\
\hline \multirow{2}{*}{$\begin{array}{c}\mathrm{AM} 2 \\
200 \mathrm{~g} / \mathrm{t}\end{array}$} & $\begin{array}{c}\text { Feed } \\
\left(\mathrm{T} \mathrm{FeS}_{2}\right)\end{array}$ & 100.00 & 5.24 & 0.87 & 44.32 & 100.00 & 100.00 & 100.00 \\
\hline & $\begin{array}{l}\mathrm{C} \mathrm{ZnO}+\mathrm{PbO} \\
\mathrm{T} \mathrm{ZnO}+\mathrm{PbO}\end{array}$ & $\begin{array}{l}17.67 \\
82.33\end{array}$ & $\begin{array}{l}8.16 \\
4.61\end{array}$ & $\begin{array}{l}0.91 \\
0.86\end{array}$ & $\begin{array}{l}39.73 \\
45.31\end{array}$ & $\begin{array}{l}27.52 \\
72.48\end{array}$ & $\begin{array}{l}18.48 \\
81.52\end{array}$ & $\begin{array}{l}15.84 \\
84.16\end{array}$ \\
\hline
\end{tabular}

Table 7. The results of the flotation of $\mathrm{Zn}-\mathrm{Pb}$ oxide minerals from calamine ore of the Pomorzany mine with AM2 hydroxyamide, with the addition of sodium sulphide in an amount of $8.0 \mathrm{~kg} / \mathrm{t}$.

\begin{tabular}{|c|c|c|c|c|c|c|c|c|}
\hline \multirow{2}{*}{$\begin{array}{l}\text { Flotation } \\
\text { conditions }\end{array}$} & \multirow{2}{*}{ Product } & \multirow{2}{*}{$\begin{array}{c}\text { Yield } \\
\%\end{array}$} & \multicolumn{3}{|c|}{ Content, \% } & \multicolumn{3}{|c|}{ Recovery, \% } \\
\hline & & & $\mathbf{Z n}$ & $\mathbf{P b}$ & $\mathrm{Fe}$ & $\mathbf{Z n}$ & $\mathbf{P b}$ & $\mathbf{F e}$ \\
\hline \multirow{3}{*}{$\begin{array}{l}\mathrm{AM} 2 \\
100 \mathrm{~g} / \mathrm{t}\end{array}$} & $\begin{array}{c}\text { Feed } \\
\left(\mathrm{T} \mathrm{FeS}_{2}\right)\end{array}$ & 100.00 & 5.30 & 0.85 & 44.37 & 100.00 & 100.00 & 100.00 \\
\hline & $\mathrm{C} \mathrm{ZnO}+\mathrm{PbO}$ & 15.37 & 9.43 & 1.03 & 35.12 & 27.35 & 18.62 & 12.17 \\
\hline & $\mathrm{T} \mathrm{ZnO}+\mathrm{PbO}$ & 84.63 & 4.55 & 0.82 & 46.05 & 72.65 & 81.38 & 87.83 \\
\hline \multirow{2}{*}{$\begin{array}{c}\mathrm{AM} 2 \\
150 \mathrm{~g} / \mathrm{t}\end{array}$} & $\begin{array}{c}\text { Feed } \\
\left(\mathrm{T} \mathrm{FeS}_{2}\right)\end{array}$ & 100.00 & 5.34 & 0.89 & 44.53 & 100.00 & 100.00 & 100.00 \\
\hline & $\begin{array}{l}\mathrm{C} \mathrm{ZnO}+\mathrm{PbO} \\
\mathrm{T} \mathrm{ZnO}+\mathrm{PbO} \\
\end{array}$ & $\begin{array}{l}17.46 \\
82.54 \\
\end{array}$ & $\begin{array}{l}9.15 \\
4.53 \\
\end{array}$ & $\begin{array}{l}1.00 \\
0.87 \\
\end{array}$ & $\begin{array}{l}36.12 \\
46.31 \\
\end{array}$ & $\begin{array}{l}29.92 \\
70.08 \\
\end{array}$ & $\begin{array}{l}19.62 \\
80.38 \\
\end{array}$ & $\begin{array}{l}14.16 \\
85.84 \\
\end{array}$ \\
\hline \multirow{3}{*}{$\begin{array}{c}\mathrm{AM} 2 \\
200 \mathrm{~g} / \mathrm{t}\end{array}$} & $\begin{array}{c}\text { Feed } \\
\left(\mathrm{T} \mathrm{FeS}_{2}\right)\end{array}$ & 100.00 & 5.24 & 0.87 & 44.32 & 100.00 & 100.00 & 100.00 \\
\hline & $\mathrm{C} \mathrm{ZnO}+\mathrm{PbO}$ & 21.12 & 8.84 & 0.97 & 37.48 & 35.63 & 23.55 & 17.86 \\
\hline & $\mathrm{T} \mathrm{ZnO}+\mathrm{PbO}$ & 78.88 & 4.28 & 0.84 & 46.15 & 64.37 & 76.45 & 82.14 \\
\hline
\end{tabular}

The structural formula of AM2 reagent is given below.

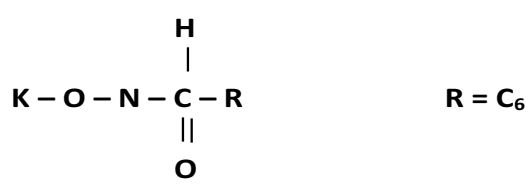

As appears from the presented data, this reagent under conditions without sulphiding operation practically does not exhibit any collecting properties with respect to the oxide minerals of lead and zinc. The $\mathrm{Zn}$ content in the froth product is slightly higher than that of the feed and the recovery 
increase with increasing dose of the reagent. It is due to the increased entrainment of fine particles to the froth product due to increased foaming. In the second step, the tests were conducted after sulphidation of $\mathrm{Zn}-\mathrm{Pb}$ oxide minerals in the feed using sodium sulphide in an amount of $8.0 \mathrm{~kg} / \mathrm{t}$. Other flotation conditions remained unchanged. The results are summarized in Table 7.

The obtained results clearly show that despite sulphidation of flotation feed, this reagent does not show good collecting properties for the $\mathrm{Pb}-\mathrm{Zn}$ oxide minerals. An increase in the $\mathrm{Zn}$ content is noticeable in the froth product (approx. $9 \% \mathrm{Zn}$ ) and increased operating recovery of zinc to about $35 \%$. However, from a practical point of view, the results are unsatisfactory.

The second examined reagent was coconut amine of the Clariant company. In the chemical sense it is a mixture of amines of various lengths of hydrocarbon radical from $\mathrm{C}_{8}$ to $\mathrm{C}_{18}$. Its fractional composition is given in Table 8.

Table 8. Fractional composition of coconut amine from Clariant company.

\begin{tabular}{|c|c|c|c|c|c|c|c|c|c|}
\hline $\begin{array}{c}\text { Trade } \\
\text { name }\end{array}$ & $\begin{array}{c}\text { Chemical } \\
\text { name }\end{array}$ & $\begin{array}{c}\text { State of } \\
\text { matter } \\
\left(\mathbf{2 0} \mathbf{C}^{\circ}\right.\end{array}$ & $\begin{array}{c}\text { Minimal concentration } \\
\text { of active substance, } \mathbf{\%}\end{array}$ & \multicolumn{6}{|c|}{ Fractional composition } \\
\hline $\begin{array}{c}\text { Genamin } \\
\text { CC 100 }\end{array}$ & $\begin{array}{c}\text { coconut } \\
\text { fatty amine }\end{array}$ & liquid & 96 & 6 & 6 & 52 & 18 & 9 & 8 \\
\hline
\end{tabular}

The experimental materials, were as previously, the tailings from marcasite flotation. Two process parameters were tested, namely the dose of sodium sulphide and dose of coconut amine. Flotation results, for varying amount of sodium sulphide, are shown in Table 9 and for varying amounts of coconut amine in Table 10.

Table 9. Results of the flotation of $\mathrm{Zn}-\mathrm{Pb}$ oxide minerals from calamine ore of the Pomorzany mine with varying amounts of sodium sulphide.

\begin{tabular}{|c|c|c|c|c|c|c|c|c|}
\hline \multirow{2}{*}{$\begin{array}{c}\text { Flotation } \\
\text { conditions }\end{array}$} & \multirow{2}{*}{ Product } & \multirow{2}{*}{$\begin{array}{c}\text { Yield } \\
\text { \% }\end{array}$} & \multicolumn{3}{|c|}{ Content, \% } & \multicolumn{3}{|c|}{ Recovery, \% } \\
\hline & & Zn & Pb & Fe & Zn & Pb & Fe \\
\hline $\mathrm{Na}_{2} \mathrm{~S}$ & $\mathrm{Feed}$ & 100.00 & 5.12 & 0.91 & 45.65 & 100.00 & 100.00 & 100.00 \\
$4.0 \mathrm{~kg} / \mathrm{t}$ & $(\mathrm{T} \mathrm{FeS}$ & \\
$\mathrm{C} . \mathrm{amine}$ & $\mathrm{C} \mathrm{ZnO}+\mathrm{PbO}$ & 11.66 & 9.63 & 1.13 & 37.11 & 21.94 & 14.48 & 9.48 \\
$200 \mathrm{~g} / \mathrm{t}$ & $\mathrm{T} \mathrm{ZnO}+\mathrm{PbO}$ & 88.34 & 4.53 & 0.88 & 46.78 & 78.16 & 85.42 & 90.52 \\
\hline $\mathrm{Na}_{2} \mathrm{~S}$ & $\mathrm{Feed}$ & 100.00 & 5.12 & 0.91 & 45.65 & 100.00 & 100.00 & 100.00 \\
$6.0 \mathrm{~kg} / \mathrm{t}$ & $(\mathrm{T} \mathrm{FeS}$ & \\
$\mathrm{C} . \mathrm{amine}$ & $\mathrm{C} \mathrm{ZnO}+\mathrm{PbO}$ & 23.20 & 14.2 & 0.86 & 31.9 & 64.36 & 21.93 & 16.21 \\
$200 \mathrm{~g} / \mathrm{t}$ & $\mathrm{T} \mathrm{ZnO}+\mathrm{PbO}$ & 76.80 & 2.38 & 0.93 & 49.8 & 35.70 & 78.48 & 83.78 \\
\hline $\mathrm{Na}_{2} \mathrm{~S}$ & $\mathrm{Feed}$ & 100.00 & 5.12 & 0.91 & 45.65 & 100.00 & 100.00 & 100.00 \\
$8.0 \mathrm{~kg} / \mathrm{t}$ & $(\mathrm{T} \mathrm{FeS}$ & \\
$\mathrm{C} . \mathrm{amine}$ & $\mathrm{C} \mathrm{ZnO}+\mathrm{PbO}$ & 22.40 & 16.3 & 1.02 & 28.95 & 71.35 & 25.07 & 14.21 \\
$200 \mathrm{~g} / \mathrm{t}$ & $\mathrm{T} \mathrm{ZnO}+\mathrm{PbO}$ & 77.60 & 1.89 & 0.88 & 50.47 & 28.65 & 74.93 & 85.79 \\
\hline
\end{tabular}

The tests carried out indicate that the optimum dose of sodium sulphide for the studied ore is approx. $8.0 \mathrm{~kg} / \mathrm{t}$, and the amine use at the level of approx. 200-220 g/t. Increasing the dose does not affect significantly the improvement of zinc recovery, while noticeable is the reduction of its content in the froth product. Significantly better results of zinc and lead oxide minerals flotation, obtained by the use of coconut amine, gave rise to a further tests performed in order to obtain a higher zinc content in the froth product by introducing a cleaning flotation of raw $\mathrm{Zn}(\mathrm{O})+\mathrm{Pb}(\mathrm{O})$ concentrate step.

As a result of introduction of cleaning flotation, an oxide concentrate containing approx. 19.8\% $\mathrm{Zn}$, and approx. $1.2 \% \mathrm{~Pb}$ with a recovery of zinc of about $38 \%$ and lead approx. $13.3 \%$ was finally obtained. The full balance of the enrichment process of studied calamine ore is shown in Table 11, while the flowsheet in Fig. 2. 
Table 10. Results of the flotation of $\mathrm{Zn}-\mathrm{Pb}$ oxide minerals from calamine ore of the Pomorzany mine with varying amounts of coconut amine.

\begin{tabular}{|c|c|c|c|c|c|c|c|c|}
\hline \multirow{2}{*}{$\begin{array}{c}\text { Flotation } \\
\text { conditions }\end{array}$} & \multirow{2}{*}{ Product } & \multirow{2}{*}{$\begin{array}{c}\text { Yield } \\
\%\end{array}$} & \multicolumn{3}{|c|}{ Content, \% } & \multicolumn{3}{|c|}{ Recovery, \% } \\
\hline & & & $\mathbf{Z n}$ & $\mathbf{P b}$ & $\mathbf{F e}$ & $\mathbf{Z n}$ & $\mathbf{P b}$ & $\mathbf{F e}$ \\
\hline $\begin{array}{c}\mathrm{Na}_{2} \mathrm{~S} \\
8.0 \mathrm{~kg} / \mathrm{t}\end{array}$ & $\begin{array}{c}\text { Feed } \\
\left(\mathrm{T} \mathrm{FeS}_{2}\right)\end{array}$ & 100.00 & 5.23 & 0.95 & 46.34 & 100.00 & 100.00 & 100.00 \\
\hline $\begin{array}{l}\text { C. amine } \\
150 \mathrm{~g} / \mathrm{t}\end{array}$ & $\begin{array}{l}\mathrm{C} \mathrm{ZnO}+\mathrm{PbO} \\
\mathrm{T} \mathrm{ZnO}+\mathrm{PbO}\end{array}$ & $\begin{array}{l}19.18 \\
80.82\end{array}$ & $\begin{array}{l}15.3 \\
2.84\end{array}$ & $\begin{array}{l}0.91 \\
0.96\end{array}$ & $\begin{array}{l}29.37 \\
50.37\end{array}$ & $\begin{array}{l}56.12 \\
43.88\end{array}$ & $\begin{array}{l}18.37 \\
81.63\end{array}$ & $\begin{array}{l}12.16 \\
87.84\end{array}$ \\
\hline $\begin{array}{l}\mathrm{Na}_{2} \mathrm{~S} \\
8.0 \mathrm{~kg} / \mathrm{t}\end{array}$ & $\begin{array}{c}\text { Feed } \\
\left(\mathrm{T} \mathrm{FeS}_{2}\right)\end{array}$ & 100.00 & 5.10 & 0.91 & 45.52 & 100.00 & 100.00 & 100.00 \\
\hline C. amine & $\mathrm{C} \mathrm{ZnO}+\mathrm{PbO}$ & 22.34 & 16.3 & 1.02 & 28.95 & 71.35 & 25.07 & 14.21 \\
\hline $200 \mathrm{~g} / \mathrm{t}$ & $\mathrm{T} \mathrm{ZnO}+\mathrm{PbO}$ & 77.38 & 1.89 & 0.88 & 50.47 & 28.65 & 74.93 & 85.79 \\
\hline $\begin{array}{c}\mathrm{Na}_{2} \mathrm{~S} \\
8.0 \mathrm{~kg} / \mathrm{t}\end{array}$ & $\begin{array}{c}\text { Feed } \\
\left(\mathrm{T} \mathrm{FeS}_{2}\right)\end{array}$ & 100.00 & 5.23 & 0.95 & 46.33 & 100.00 & 100.00 & 100.00 \\
\hline C. amine & $\mathrm{C} \mathrm{ZnO}+\mathrm{PbO}$ & 28.83 & 13.71 & 1.1 & 28.72 & 75.52 & 33.36 & 17.87 \\
\hline $260 \mathrm{~g} / \mathrm{t}$ & $\mathrm{T} \mathrm{ZnO}+\mathrm{PbO}$ & 71.17 & 1.8 & 0.89 & 53.47 & 24.48 & 66.64 & 82.13 \\
\hline
\end{tabular}

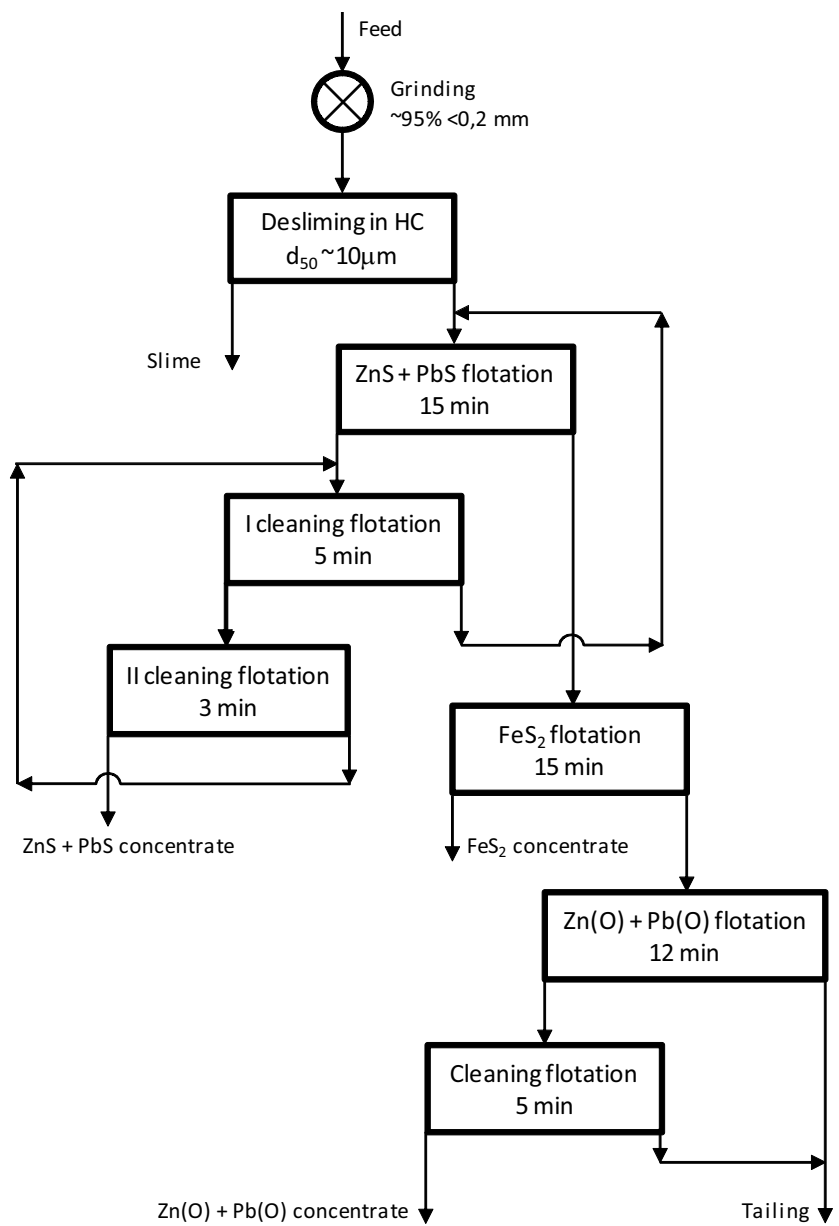

Figure 2. Flowsheet for recovery of $\mathrm{Zn}-\mathrm{Pb}$ sulphide and oxide minerals from calamine ore of the Pomorzany mine. 
Table 11. Balance of the recovery process of $\mathrm{Zn}-\mathrm{Pb}$ sulphide and oxide minerals from the calamine ore of the Pomorzany mine.

\begin{tabular}{|c|c|c|c|c|c|c|c|}
\hline \multirow{2}{*}{ Product } & \multirow{2}{*}{$\begin{array}{c}\text { Feed } \\
\%\end{array}$} & \multicolumn{3}{|c|}{ Content, \% } & \multicolumn{3}{|c|}{ Recovery, \% } \\
\hline & & $\mathbf{Z n}$ & $\mathbf{P b}$ & $\mathbf{F e}$ & $\mathbf{Z n}$ & $\mathbf{P b}$ & $\mathbf{F e}$ \\
\hline Feed & 100.00 & 5.61 & 0.97 & 43.51 & 100.00 & 100.00 & 100.00 \\
\hline Slime & 15.53 & 5.27 & 1.06 & 42.38 & 14.59 & 16.97 & 15.13 \\
\hline HC underflow & 84.47 & 5.67 & 0.95 & 43.72 & 85.41 & 83.03 & 84.87 \\
\hline $\mathrm{C} \mathrm{ZnS}+\mathrm{PbS}$ & 2.59 & 53.24 & 3.54 & 5.32 & 24.62 & 9.47 & 0.32 \\
\hline $\mathrm{C} \mathrm{FeS}_{2}$ & 21.64 & 0.71 & 0.80 & 44.28 & 2.74 & 17.85 & 22.02 \\
\hline $\mathrm{C} \mathrm{Zn}(\mathrm{O})+\mathrm{Pb}(\mathrm{O})$ & 10.75 & 19.82 & 1.20 & 26.14 & 37.98 & 13.30 & 6.46 \\
\hline $\mathrm{T} \mathrm{Zn}(\mathrm{O})+\mathrm{Pb}(\mathrm{O})$ & 49.49 & 2.28 & 0.83 & 49.30 & 20.07 & 42.41 & 56.07 \\
\hline
\end{tabular}

\section{Summary}

The studied calamine ore from the Pomorzany mine was characterized by an unusual mineral composition. With an average zinc content approx. 5.6\% Zn, including 3.6\% Zn (O), and lead approx. $0.95 \%$, with the approx. $0.73 \% \mathrm{~Pb}(\mathrm{O})$, the iron content was approx. $43.7 \% \mathrm{Fe}$ of which approx. $13.8 \%$ Fe was present as an iron sulphide and approx. $29.9 \% \mathrm{Fe}$ as an iron oxide. The mineralogical analysis showed that the main component of the ore was goethite, which part was of the approx. $46.8 \%$, and marcasite in an amount of approx. 29.6\%. Oxide minerals of zinc in an amount of approx. $13.3 \%$ mainly occured as monheimite being ferruginous variety of smithsonite.

The high share of goethite in ore makes it necessary to introduce, prior to flotation, the desliming process in order to remove from the flotation feed the finest colloidal particles composed mainly of iron hydroxides passing to the slurry in the grinding process. The introduction of preliminary desliming process allows for separation from the ore the sulphide $\mathrm{Zn}-\mathrm{Pb}$ bulk concentrate containing approx. 53.2\% $\mathrm{Zn}$, and approx. $3.5 \% \mathrm{~Pb}$ with a recovery of zinc of approx. $24.6 \%$ and lead of approx. $9.5 \%$.

The high share of marcasite in the ore requires its separation before flotation of $\mathrm{Zn}-\mathrm{Pb}$ oxide minerals. The most preferred conditions of this process are after initial sulphidizing its surface with sodium sulphide in an amount of approx. $500 \mathrm{~g} / \mathrm{t}$, and then flotation using sodium ethyl xanthate in an amount of approx. $100 \mathrm{~g} / \mathrm{t}$ for $15 \mathrm{~min}$. Under these conditions, approx. $22 \%$ of the ore in the form of iron sulphide concentrate containing approx. $44.6 \%$ Fe is extracted to the froth product.

Among the studied collecting reagents for flotation of $\mathrm{Zn}-\mathrm{Pb}$ oxide minerals, coconut amine, which is a mixture of primary aliphatic amines with a carbon number in radicals of $\mathrm{C}_{8}-\mathrm{C}_{18}$, shows the best flotation properties. The second tested reagent from the hydroxyamide group does not show any significant collecting properties for the $\mathrm{Zn}-\mathrm{Pb}$ oxide minerals, both under conditions without and with addition of sodium sulphide.

The most beneficial flotation results of $\mathrm{Zn}-\mathrm{Pb}$ oxide minerals are obtained under condition of the addition of sodium sulphide to the suspension in the amount of approx. $8.0 \mathrm{~kg} / \mathrm{t}$ and coconut amine in the amount of approx. 200-220 g/t. In the studied flowsheet, an $\mathrm{Zn}-\mathrm{Pb}$ oxide concentrate containing approx. $19.8 \% \mathrm{Zn}$, and approx. $1.2 \%$ of $\mathrm{Pb}$ with a recovery of zinc of approx. $38 \%$ and lead of approx. $13.3 \%$ was achieved. A relatively low content of zinc in concentrate is due to its occurrence in monheimite, which contains, next to $\mathrm{Zn}$ atoms also Fe atoms in its crystal lattice.

\section{References}

1. K. Cichy, R. Luczak, A. Manka, IMN report No. 6997 (2011)

2. K. Cichy, R. Luczak, A. Manka, IMN report No.7029 (2012) 